\title{
Flight attendants and emotional intelligence: a case study of Thai airways flight attendants
}

\author{
Kanittha Charernnit ${ }^{1, *}$ \\ ${ }^{1}$ College of Hospitality Industry Management, Suan Sunandha Rajabhat University, Bangkok, \\ Thailand
}

\begin{abstract}
After the COVID-19, also known as coronavirus has spread widely and crashed all industries especially airline business industry, causing suspension in their operational which resulting in financial losses. Many airlines all over the world has to cut off the salary of their employees or lay-off their employees to maintain their financial status. This put many airlines employees' financial and emotional instability. The primary focus of this research is to study Thai Airways' flight attendance emotional intelligence after the suspension of the flight operational from COVID-19 crisis and to recommend a guideline referring to the $U$ theory and Buddhism beliefs to develop emotional intelligence. A survey was conducted among 31 flight attendants of Thai airways with no leadership position. This research presents guidelines for developing emotional intelligence for flight attendants based on the best knowledge available on how to promote and emotional learning especially after flight suspension during COVID-19.
\end{abstract}

\section{Introduction}

Since the World Health Organization (WHO) declared the outbreak of Corona virus as Public Health Emergency of International Concern in January 2020 and a pandemic in March 2020 [1]. The strictly process to handle the pandemic has been announced and implemented worldwide. The air transportation is one of the transportations that could possibly transfer the virus from one place to another place, from one country to another country, meaning that it can be spread exponentially all over the world. Therefore, the seizing in air transportation has been implemented to all airlines all over the world since then.

The airline transportation Industry is getting direct impact from the pandemic which resulting in flight cancellation, flight suspension. Thai airways, the national airline of Thailand, had been losing money for many years and seek help immediately. [2] The bankruptcy court approved a business rehabilitation plan in 2020 after the coronavirus pandemic caused the grounding of most of its fleet, adding to its liquidity woes.

Thai airways, have to reduce the workforce, with almost 5,000 employees having signed up for the company's early retirement scheme, also employees were allowed to take voluntary leave without pay or allowed to make a choice to join an early retire program or a

\footnotetext{
* Corresponding author : kanittha.ch@sssru.ac.th
} 
worst case, receiving a package for financial assistant plus remuneration on a laid-off scheme.

There are an increasing number of laid-off flight attendants and employee who were allowed to take leave without pay. Even the Thai Airways subsidiary company "Wingspan" had laid of almost 2,600 employees in 2020. [3] The State Enterprises Workers' Relations Confederation stated that the company had let go the employees as of September 1, due to THAI flights being suspended since the end of March 2020.

The current employees are being frustrated about their future career, moreover, being frustrated about their financial burden which will be occurred in a very near future. With all these conditions, they need a new range of skills to face the new chapter in their life together with their emotional intelligence to handle all the burden which will attack their attitude to live their life. However, no one knows the future, unless the people know how to be a life-long learner and have the right attitude to adapt themselves to the changes. Many researchers, have studied on emotional intelligence [4] Lundberg \& Westerman (2020) suggested that the workforce should be educated to be able to learn and grow which focus on developing attitudes and behaviour. Since the attitude of thinking could leads to action whether positive or negative. This paper may be applicable to the management of airline in terms of business practice during flight suspension from COVID-19. The organization may use emotional intelligence to enhance employee relation within their organization in the future when they are back on track after the pandemic. In this paper, the researcher aims to highlight the emotional intelligence referring to $U$ theory and Buddhism beliefs which recommend people to manage their thinking, their attitude and their mind in a positive way whether the goods or bad happened in their life.

\section{Theoretical Analysis}

This section explains several concepts especially related to this paper. In this paper, the researcher conducts the survey and the majority of respondent from Thai airways flight attendants were female accounted for $91 \%$ and were male at $9 \%$. There were 31 percent, 35 percent and 34 percent who working with Thai airways for 25 years, 20 years and 10 years respectively. From the survey, it is worth knowing that all employees are worrying about their job and their future career path.

More importantly, 98 percent of the respondents are worrying about their company's bankruptcy scheme which could affect to the payment schedule to employees and to debtors. 82 percent of respondents needs financial assistance after laid-off scheme. 73 percent has no plan for their next job after laid-off scheme. Currently, 98 percent of respondents are frustrated about the instability of the airline industry that was affected by corona virus, as flights were cancelled, and suspended with unforeseeable future as no exact date of returning to normal flight operations.

Flight attendants' roles and responsibility can be described as the service staff on board the airplane which can also be called as a "Cabin Crew". [5] Sveins et al, (2007) defined the cabin crew job as a service-oriented and mostly performed by females who are expected to serve the passenger's individual needs to multiple requests on board.

In the past several models of human behaviour have been developed. The most common model was developed in the 1940s by [6] Abraham Maslow he believed that an individual's behaviour is established by the individual's strive to meet essential human needs, which he identified as physiology needs, safety and security needs, needs of love and belongingness, self-esteem and self-actualization needs. Maslow located these needs into a conceptual hierarchy or pyramid that ranks them according to individual needs. Individual has to meet their needs at the base of the pyramid before levelling to the higher needs on the pyramid. 
Those needs spotted higher on the pyramid are not an essential basic requirement for life for physiology needs but rather strengthening it.

On the other hand, people's behaviour or action in Buddhism called "Karma" which derive from three types of actions as action derive from physical, action derive from verbal and action derive from thinking. Moreover, [7] the action of people depends on the value, perception, attitude, and personality they have within. The value is the believe, attitude, norms which lead to action and practice. When we have a closer look on Buddhism believes, it said that peoples' attitude should be neutral from the fifth elements which consists of eye-seeing, ear-hearing, nose-smelling, tongue-tasting, body-touching. While the $U$ theory [8] (Schrmer, 2009) described that the theory seeks to declare the hidden dimension of social that people faced every day. The U theory also was proposed by Albeit, which he said that leaders, individuals or group of people should apply this theory in their life to handle with the frustration or fluctuate situation.

The $U$ theory describes the knowledge from cognitive thinking that one shall have a freedom of thinking focusing on observance, perceiving and realizing the knowledge as an initiative and creativity. Senge et al. (2004), describe the U theory that people's knowledge and creativity derive from observing and reflecting the knowledge with natural flow which means one can connect to the deepest inner knowledge within their thought and then emerge the inner knowledge into practices [9].

The model of $U$ theory shown in figure 1 . starts from sensing, presencing, and realizing.

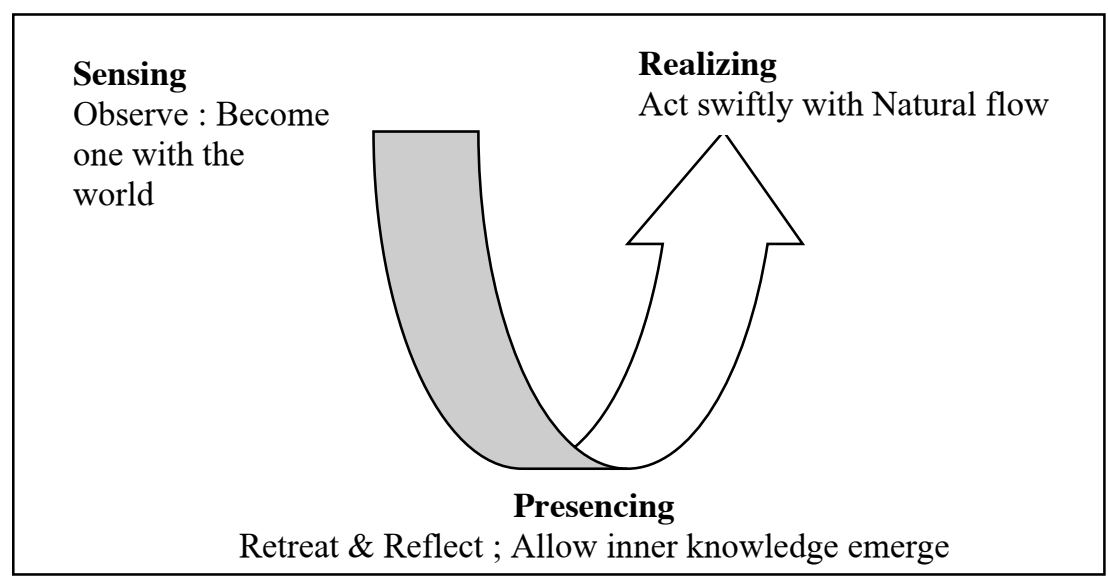

Fig. 1. Sensing Source. Source: Adapted from Senge et al. (2004). Presencing. Page.88.

In addition, emotional intelligence has been widely discussed among the academic and business world, emotions are recognized as fundamental of mental operations, while intelligence conceptualized as abstract thinking. [10] pointed that intelligence is used differently by different people. Moreover, the mental ability model was presented by [11] that intelligence is high-level mental ability such as abstract reasoning or abstract thinking.

The emotional intelligence of individuals also has been described by [8] that one must be open mind, must be open heart and must be open will. This can be concluded that the open mind is the intellectual quotient (IQ), open heart is emotional quotient (EQ) which involves the emotion in oneself as knowing how to calm down after feeling angry or ability to manage their anxiety, open will is spiritual quotient (SQ) which is more likely to appear in an authentic self-esteem.

Furthermore, from [12,13] explained that the $U$ theory is to instruct people to avoid using their experience to judge without cogitate. The theory guides people to use their analytical thinking skills, logical skills, and problem-solving skills effectively. In addition, emotional intelligence is a type of social intelligence that involves the ability to monitor 
one's own and others' emotions, and guide one's thinking and actions in a positive way $[14,15]$. For this reason, the researcher sees the potential that flight attendant and organization can adapt an emotional intelligence learning and $U$ theory with Buddhism beliefs for flight attendants who suffer from their job their roles and responsibility and from the flight suspension from COVID-19 accordingly.

\section{Conclusion and recommendations}

In summary, airline employees all over the world were in a dilemma in the wind during airline suspension from COVID -19 pandemic. The emotional intelligence of flight attendants became essential as there were instability situation in airline industry. As the terms, emotional intelligence focus on mental abilities to deal with unplanned situation and how one can cope with the problem, find out reason and conduct problem solving accordingly. Becoming the flight attendant is considering as the airline frontline service employees, they are in direct contact with passengers and have to deal with high emotional demands of passengers, as well as flight suspension from COVID-19 which resulting in no flight no work, no money which related to financial burden for them.

Therefore, their emotional intelligence or emotional skills are affecting their ability to deal with the emotions of high demand passenger and their own problem accordingly. At present it would be beneficial for flight attendants to understand the U-theory and apply Buddhism beliefs to manage their own emotions and are able to anticipate this while dealing with the burden from flight suspension from COVID-19 pandemic and be able to focus on their needs and future career path.

The benefits of emotional skills are not only to manage crucial passengers who are emotional, but also regulate the employee's emotions so that they can handle with the unreasonable demands and unplanned situation respectively. Finally, it can be noticing that, there are various ways to reduce stress of the flight attendant that happen during flight suspension from COVID-19. The understanding of the pandemic situation around the world and understanding others by using U-theory and Buddhism beliefs enhance the emotion intelligence of flight attendants who get affected from the flight suspension which resulting in jobless or laid-off from work at the same time.

\section{References}

1. COVID-19 pandemic (2020) http://www.wikepedia.com

2. Thai Airways puts 34 planes up for sale (2020) http:// bangkokpost.com

3. The Thaiger. Laid off workers ask for financial assistance after Thai Airways flight suspension (2020) http:// www.thethaiger.com

4. A. Lundberg, G. Westerman, The transformer CLO (2002) http://www.hbr.org

5. H. Sveins, H. Gunnars, H. Fridriks, Self-assessed occupational health and working environment of female nurses, cabin crew and teachers (2007)

6. S. McLeod, Simply Psychology. Maslow's Hierarchy of Needs (2020) http://www.simplypsychology.org/maslo

7. C. Wichuda, Human relations and personality development (2009)

8. O.C. Scharmer, Theory U: leading from the future as its merges (2009)

9. P. Senger, O.C. Scharmer, J. Jaworski, B.S. Flowers, Presence: human purpose and the field of the future (2004) 
10. H. Gardner, Expanding our concept of intelligence: What's missing and what could we gain? "Who owns 'intelligence?'” (1997)

11. R.J. Sternberg, A broad view of intelligence: The theory of successful intelligence (2003)

12. K. Kannapat, Mindset development by applying $U$ theory and religious concept in educational system: Thailand as a case (2020)

13. D. Ushakov, International J. of Environmental and Science Education 11(18), 12937 12945 (2016)

14. H.L.T. Mai et al., International J. of Recent Technology and Engineering 8(2.11), 3876-3882 (2019)

15. A.H. Tran et al., International J. of Recent Technology and Engineering 8(2.11), 38833888 (2019) 